\title{
Women and Money: Unique Issues - Your Money Matters ${ }^{1}$
}

\author{
Diann Douglas and Martie Gillen²
}

Societal dynamics and their effects on gender roles and family structures underscore a distinct need for financial management education to address the unique issues that women may encounter. This series of EDIS publications, "Women and Money: Unique Issues," encompasses financial management for women across the life cycle and through family transitions. This series focuses on the changes women may encounter throughout their lives and the impact of these changes on their economic status. For the rest of the publications in the series, see http://edis.ifas. ufl.edu/topic_series_women_and_money_unique_issues.

\section{Overview}

\section{Money Impacts Marriage}

As you probably learned throughout your life, money has a powerful influence in and on people's lives. Money pays the bills; it buys the things people want and need. Many of people's conversations are about money. That is why couples considering a future together should discuss money before they marry. Discussing money may not be the most romantic gesture, but this is an important conversation to have early in a relationship and to continue to have throughout your marriage.

Why should you talk with your partner about money? Money problems are often identified as the cause of disagreements among married couples and frequently the cause of divorce. In fact, researchers found that “....couples who reported disagreeing about finances once a week were over 30 percent more likely to divorce over time than couples who reported disagreeing about finances a few times per month" (Dew 2009, p. 28).

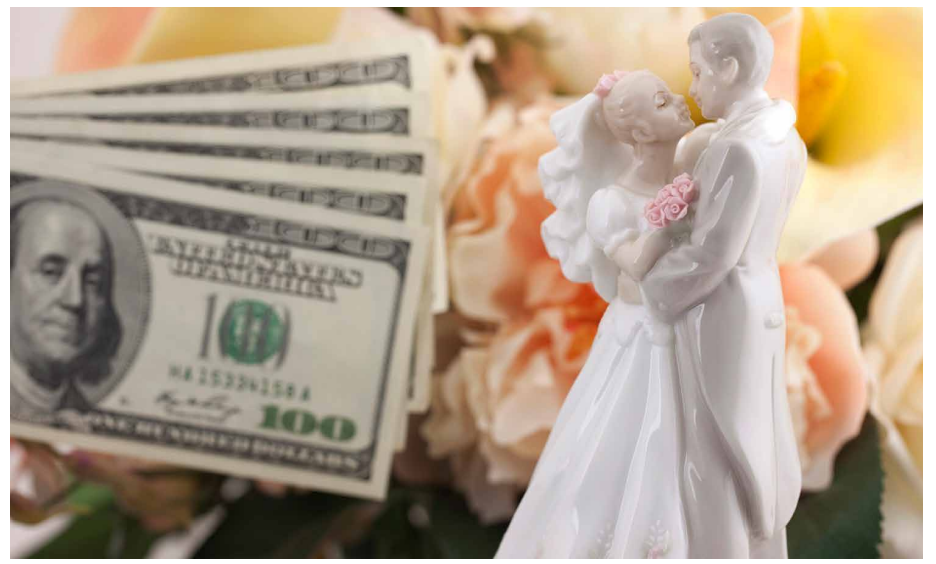

Figure 1. Talking about money may not seem like a romantic gesture, but make sure you talk with your significant other about your finances before you marry.

Credits: iStockphoto

In other words, money can be a major source of conflict for couples. It takes open communication and a willingness to resolve problems to keep a couple on track with their money. Couples who create a successful relationship have money problems, too. What is their secret? They have figured out ways to talk about money with each other and

1. This document is FCS2180, one of a series of the Department of Family, Youth and Community Sciences, UF/IFAS Extension. Original publication date: September 2000. Latest revision: September 2013. Visit the EDIS website at http://edis.ifas.ufl.edu.

2. Diann Douglas, M.S., county Extension director and Extension agent IV, UF/IFAS Extension Madison County, and Martie Gillen, assistant professor and Family and Consumer Economics for Older Adults specialist, Department of Family, Youth and Community Sciences; UF/IFAS Extension, Gainesville, FL 32611.

The Institute of Food and Agricultural Sciences (IFAS) is an Equal Opportunity Institution authorized to provide research, educational information and other services only to individuals and institutions that function with non-discrimination with respect to race, creed, color, religion, age, disability, sex, sexual orientation, marital status, national origin, political opinions or affiliations. For more information on obtaining other UF/IFAS Extension publications, contact your county's UF/IFAS Extension office. 
have agreed on how they will handle money in their life together.

\section{Talk About Money Before You Marry}

\section{Why Couples Don't}

Couples seldom discuss the topic of money before marriage. Money is generally viewed as a taboo topic. It just isn't romantic to talk about income and debts. But talking about money openly and honestly is the only way to start a marriage. Ignoring problems does not make them disappear.

\section{Consider These Case Studies}

\section{Case Study 1}

Ron and Lynn dated a year before they became engaged. Ron was very romantic, sending flowers for special occasions and taking Lynn for dinner to fine restaurants. There were expensive gifts - a beautiful diamond ring and a honeymoon cruise. A few months after the wedding, Lynn was shocked to find out that Ron owed \$12,000 in credit card debt and $\$ 40,000$ in student loans, much of it acquired while they were dating. Lynn had never asked how Ron had paid for the gifts and had no idea it all went on charge cards.

\section{Case Study 2}

Before Mike and Sandy married the subject of salaries or bills never came up. Mike had a good paying job, and Sandy also worked and paid her half of the monthly bills. Sandy was often stretched to pay her share, but Mike always seemed to have extra money. He never hesitated to buy anything he wanted, while Sandy never had extra money to spend for herself. Sandy knew his salary was twice the amount of her own, but she felt uncomfortable talking to Mike about their financial arrangements.

\section{The Fallout from Silence}

Imagine the shock of learning your new spouse owed a large amount of money for credit card bills and student loans and had never mentioned it.

Imagine the pain of feeling the money arrangement was unevenly balanced. If the couples in these case studies had been open and talked about money before their marriage, they could have started their marriages on the right foot with open communication.

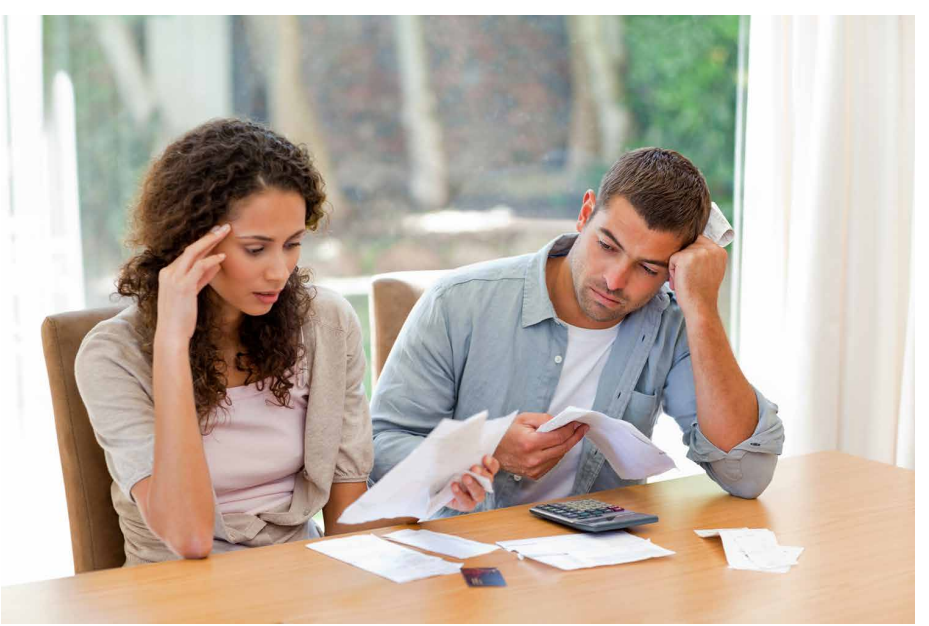

Figure 2. Married couples can prevent arguments about finances if they honestly and openly discuss money.

Credits: Wavebreak Media

\section{Know Your Own Values and Attitudes}

Couples planning on a permanent relationship need to understand that each one comes into a marriage with their own set of values. Values are what is important to you as an individual. Your personal attitude toward money is highly influenced by your value system.

Two people with different value systems could have difficulty where money is concerned. For example, one person may value spending money while the other might value saving it. That's a built-in conflict (saver vs. spender) but not the only one that can affect a marriage.

You might think that partners with matching values have less potential for disagreement, but that is not necessarily the case. Two savers could have a major disagreement on how to invest money. Two spenders could run out of money before the end of the month. Either situation could cause a disagreement.

\section{How and Where Did You Get Your Values?}

The way your family handled money has a major influence on your personal money management style. In some families, the mother was the bookkeeper and check writer, while in another family the father took the responsibility.

Some people may have been raised in a family where nothing was paid on time and bill collectors called on a regular basis. These childhood experiences affect money habits. The key is to learn about each other's experiences and blend your styles for handling money. 


\section{Money Can Be an Emotional Issue}

Money can become an emotional weapon when a couple is going through a difficult time. For example, if one spouse is angry at the other, a spending spree may be a way to get even or ease hurt feelings. The result is an increase in debt.

If a couple has an argument, an expensive gift might be purchased to apologize, but again, it adds to the family debt.

What needs to happen in these situations is a heart-to-heart talk, not a major purchase or spending spree. Money should not be used as a way to get even or apologize.

\section{Blending Incomes}

Couples can decide how they want to handle money.

Whether you have one or two incomes, couples need to discuss how they will handle finances. Two-income couples can consider several different methods for managing the family's money.

\section{Equal Share}

Each person puts an equal amount of their paycheck into a joint checking account to cover basic household expenses. Equal amounts are also contributed to a joint savings account. The remainder can be saved or spent as each person decides (Molgaard 1991).

\section{ADVANTAGES}

- Each spouse contributes to both daily and long-term expenses.

- Each has some money to call his/her own.

\section{DISADVANTAGES}

- One spouse may earn less money, so the contribution leaves little personal money and may lead to resentment.

\section{Proportional Share}

Each spouse contributes a percentage of his/her income to cover household expenses and joint savings. The remainder is his/hers to do with as each pleases (Molgaard 1991).

\section{ADVANTAGES}

- Both spouses contribute to household expenses and items they purchase.

- Each has some money to call his/her own.

\section{DISADVANTAGES}

- The higher income earner has more personal money.

\section{Poolers}

Both paychecks are deposited into a joint account and used for both household and personal expenses.

\section{ADVANTAGES}

- The work of each spouse is valued equally, regardless of income earned.

- Record-keeping is simplified.

\section{DISADVANTAGES}

- Both spouses may feel obligated to discuss all purchases with each other.

- Couples need to determine an "allowance" for each spouse.

\section{Dealing with Money}

- Share information about your income and debts before you marry. Make a habit of talking with your spouse about money and work on a spending plan.

- Obtain your credit report and discuss the report with your significant other.

- Never hide debt from your spouse; it creates a tremendous amount of stress on both sides.

- Agree on financial goals. It takes compromising on some issues, but it is all part of marriage.

- Establish a spending plan to direct where your money will go.

- Set up a household record-keeping system.

- Have a date to discuss your finances with your spouse each month to determine how you're doing financially.

- Make adjustments in your spending plan if it is not working.

- Build an emergency savings account for unexpected expenses.

- Use purchasing practices that reduce spending and redirect money into savings.

- Get into the habit of paying for items with cash.

- Limit your total consumer debt to $20 \%$ of your take-home pay. (Consumer debt is car payments, credit card payments-everything but your house.)

- Learn about income taxes. The rules are different for married couples. You may find it to your advantage to itemize your deductions.

- Learn about insurance. Investigate the costs of health insurance and life insurance. 


\section{References}

Dew, J. 2009. The State of Our Unions - Marriage in 2009.

Bank on It: Thrifty Couples Are the Happiest. Accessed

September 2013. http://www.stateofourunions.org/2009/ bank_on_it.php.

Molgaard, Virginia. 1991. Managing Two Incomes: Yours, Mine and Ours. Ames: Iowa State University.

Torres, Nayda, and Vervil Mitchell. 1995. Making Financial Plans Together. FCS7010. Gainesville: University of Florida Institute of Food and Agricultural Sciences. 